\title{
INNOVATIVE DEVELOPMENT: MODEL AND EVALUATION METHOD IN THE CONTEXT OF INTEGRATION PROCESSES
}

\author{
Valentyna Diatlova ${ }^{1}$, Yuliia Diatlova ${ }^{2}$, Iryna Petryk ${ }^{3}$, Yuliia Hutareva $^{4}$, Tetyana Zubro ${ }^{5}$, Olena Tyshchenko ${ }^{6}$ \\ ${ }^{1}$ Prof. Dr. Sc. (Econ), Donetsk State University of Management. Karpinskoho str. 58. 87513. Mariupol. Ukraine. Phone \\ Number+380951582533, E-mail address dyatlovi@inbox.ru \\ ${ }^{2}$ Assoc. Prof. Dr. Sc. (Econ), Donetsk State University of Management. Karpinskoho str. 58. 87513. Mariupol. Ukraine. \\ Phone Number +380500471466, E-mail address yuliyadyatlova25@gmail.com
}

${ }^{3}$ PhD student, Donetsk State University of Management. Karpinskoho str. 58. 87513. Mariupol. Ukraine. Phone Number+380983707845, E-mail address petrik.irina1991@gmail.com

${ }^{4}$ PhD of Econ., Odessa National Polytechnic University. Shevchenko av. 1. 65044. Odessa. Ukraine. Phone Number +380676011785, E-mail address j.v.gutareva@mzeid.in

${ }_{5}^{5}$ Assis. Prof. PhD, University of Economics in Bratislava. Dolnozemská cesta. 1. 85235. Bratislava. Slovakia. Phone Number+421902658030,E-mail address tetyana.zubro@euba.sk

${ }^{6}$ Assoc. Prof. PhD of Econ., Volodymyr Dahl East Ukrainian National University. Tsentralnyi Prospect. 59-a. 93406. Severodonetsk. Ukraine. Phone Number+380508559681, E-mail address tyshchenko_olena7@ukr.net

Received 25012021 ; Accepted 01032021

\begin{abstract}
Development in the modern world is based on innovation. Many scientists are investigating the problem of innovative development. Most researches agree that innovation is the main driving force for economic and society development, solving environmental problems. The transition to an innovative development model is a priority issue for many countries. Ukraine is no exception, in which the national innovation system has just begun to form. This determines the relevance of the research. The aim of the article is to substantiate the methodological approach to assessing the socioecological and economic system of the country in the conditions of innovative development. In our opinion, the modern trajectory of innovative development is ensured not only by the presence of a national innovation system, but also by the innovativeness of the all sphere of country's vital activity, the main components of which are the social, ecological and economic systems. The innovativeness of the systems is proposed to be evaluated as an integral indicator, which is calculated of certain indices. The list of indices for economic, social and ecological systems is offered. The EU values with the best result were used as standard. The complex indicator are calculated of integral indicators and allows determining the position of Ukraine in comparison with the EU countries.
\end{abstract}

Keywords: complex indicator, evaluation method, indices, innovative development, integral indicator, model of basic systems, socio-ecological-economic system innovativeness, integration processes.

JEL Codes: O11, O30.

\section{Introduction}

The experience of world's leading countries testify that the main condition for long-term positive rates of economic growth, social development and environmental changes is the transition to an innovative development model due to the active introduction of innovations in all spheres of the country's vital activity.

Scientists emphasize the need to study modern systems of life and activity in the country. In most scientific works of the XX century, social and economic systems are recognized as the main, which have been studied by scientists in the interrelation and in

Copyright (C 2021 Author(s), published by Vytautas Magnus University. This is an open access article distributed under the terms of the Creative Commons Attribution Non-Commercial 4.0 (CC BY-NC 4.0) license, which permits unrestricted use, distribution, and reproduction in any medium provided the original author and source are credited. The material cannot be used for commercial purposes. 
various aspects. In the XXI century, the problem of ecology security became widespread, so research on the development of countries is aimed at solving social, economic and ecology issues (Gurman, Matveev, Trushkova, 2013; Matvieieva, Myroshnychenko, Valenkevych, 2019; Rosser, 2001). Scientists emphasize the use of renewable energy sources as a strategic approach to changes in ecology and social policy, business models in the economy (Alvarez-Herranz, Balsalobre-Lorente, Shahbaz, Cantos, 2017; Diatlova, Petryk, 2019; Li, Shen, 2019; Nesta, Vona, Nicolli, 2014). It is recognized by scientists and practitioners that the introduction of an innovation system becomes the basis for solving social, economic and ecology problems (Bristow, Healy, 2018).

The formation of the innovation system in Ukraine is in its infancy, as in many other countries. Therefore, scientists and practitioners pay considerable attention to this issue (Zvieriakov, Zavadska, 2018). After all, it is the effective functioning of the innovation system that will make it possible to switch to the path of the country innovative development, to resolve many issues of a social, economic and ecology nature, taking into account the goals of sustainable development. Innovative activity is the basis for increasing the efficiency and competitiveness of Ukrainian business (Tanashchuk, Kovtunenko, Kovtunenko, 2018).

From these positions, it is important to understand the innovative nature and interrelation of the main systems in the country's vital activity (Coccia, 2014; Holmén, Magnusson, McKelvey, 2007), the innovative development model and methods of its evaluation. The importance of the transition to innovative development is recognized at the international and national levels. However, some critics deny the enormous benefits of innovation as primary driving force for economic growth and social progress (Wang, Miao, 2020).

Researches believe that the country's modern systems of life and activity are complex and function in conditions of instability and systemic crises (Rosser, 2001). Many scientists have devoted their research to forecasting and modeling trends in the development of such systems (Janssen, 1998). In order to predict the development of an innovation economy, the nonlinear integral stochastic model of growthing dynamic in the phase space has been investigated and developed on the basis of modern mathematical models, methods and information (Ramazanov, Antoshkina, Babenko, Akhmedov, 2019).

To solve the problems of forecasting and modeling the innovative development of socioeconomic systems and structures scientists have systematized the existing models and methods, specified the factors that are used in them (Zos-Kior, Hnatenko, Isai, Shtuler, Samborskyi, Rubezhanska, 2021; Gurman, Matveev, Trushkova, 2013). Researches have determined that the method of mathematical macro-modelling is based mainly on the resource factor, and the method of foresighttechnologies (technologies of future formation) is mainly based on two factors - technology and resources. Three variables, such as nation, technology and resources, are recommended for use in the method of global integral forecasting of world dynamics. In this case, the capital factor is excluded from the integral forecasting. It is believed that in nonlinear mathematical models describing the dynamics of the complex systems development, the relationship and interdependence of all variables are used (Dudin, Lyasnikov, Veselovsky, Sekerin, Aleksakhina, 2014).

In a separate study, scientists presented the model of socio-ecological-economic system of the region and carried out calculations related to the evaluation of its state and functioning. For calculations, a set of indicators was used, including individual and integral indicators of the complex systems functioning, considered as socio-ecological-economic systems. Statistical data were used for calculations (Zhukov, 2018).

A complex indicator for evaluation the state of development of a country or its region is used in most studies and world rankings (Matvieieva, Myroshnychenko, Valenkevych, 2019; Anopchenko, Paytaeva, Novoseltseva, 
Management Theory and Studies for Rural Business and Infrastructure Development

eISSN 2345-0355. 2021. Vol. 43. No. 1: 161-171

Article DOI: https://doi.org/10.15544/mts.2021.14

Chernyshev, Murzin, 2015). To compare the EU regions according to their level of innovation, scientists proposed an approach based on the multi-criteria taxonomic method. For many years, a taxonomic method based only on the mean has been used to evaluate the innovative level of development of the EU countries and regions. Meanwhile, the main goal of this kind of analysis should include an evaluation of results compatibility obtained in different areas constituting a complex indicator. According to the multi-criteria taxonomic method, the level of innovation in each region of the EU is evaluated using the results for each group of indicators, respectively of the areas considered. As a result, the EU regions can be divided into groups according their level of innovation in all considered areas, and not only according to their mean value of development. An additional value of method is the ability to obtain information about the internal structure of innovations in the socio-economic systems of the EU regions (Szopik-Depczyńska, Cheba, Bąk, Kędzierska-Szczepaniak, Szczepaniak, Ioppolo, 2020).

The world rankings are based on the use of a complex indicator, which is compiled using certain indices. Ratings are very important for countries and the world community, as they serve as indicators of social, economic, environmental, political and other processes. The rating of the Global Innovation Index is important for evaluating innovation processes. The Global Innovation Index 2019 compares the innovation activities of 129 countries and economies around the world (Dutta, Lanvin, Wunsch-Vincent, 2019). Switzerland was recognized as the most innovative country, followed by USA, the Netherlands and the United Kingdom. In the 2020 report, the order of the countries is as follows - Switzerland, Sweden, United States and the United Kingdom. In 2020, Ukraine improved its result by two positions and took 45th place in the Global Innovation Index, entering the TOP-2 countries of the lowermiddle income economic group.

All countries that lead the global rankings use an innovative development model. So far, no universal model of innovative development has been developed. This is due to many factors: the geographical features of countries; the pace of scientific and technological development, which is significantly ahead of existing methods of managing innovation processes; uneven development of information technologies infrastructure in countries and regions; unpredictability of innovative development processes on the part of the state and business structures, etc. There are four models of innovative development in the world: EuroAtlantic, East Asian, alternative and the triple helix model (Burduli, Abesadze, 2017). None of these models is used by any country in its pure form.

Each country forms its own innovative model. Thus, the research proposes the transition and implementation of the fourth spiral model of the Ukrainian economy innovative development (Zvieriakov, Zavadska, 2018). In our opinion, it is necessary to substantiate the approach to building a model and the method of its evaluation.

\section{Research results and discussion}

Each country builds a model of innovative development, choosing specific its driving forces. This approach allows to accumulate financial resources for innovative development within such driving forces and to create from them certain success factors. There are four models of innovative development (Euro-Atlantic, East Asian, alternative, triple helix), based on different driving forces (Burduli, Abesadze, 2017).

The world has formed an opinion regarding the priority development of Ukraine

Copyright (C) 2021 Author(s), published by Vytautas Magnus University. This is an open access article distributed under the terms of the Creative Commons Attribution Non-Commercial 4.0 (CC BY-NC 4.0) license, which permits unrestricted use, distribution, and reproduction in any medium provided the original author and source are credited. The material cannot be used for commercial purposes. 
as an agricultural country. We agree with the view of domestic scientists and practitioners that the application of a model with the predominant applying of innovative technologies from other countries limits the innovative development of Ukraine. When building an innovative model, it is important to determine the approach to evaluating its result.

The analysis of scientific research has shown that the sphere of the country's life is complex and its main systems are social, ecological and economic. We propose to understand the innovative model of development as such, the central element of which is innovation, the comprehensive nature of which due to the national innovation system is aimed at all components of the socioecological-economic system in the country (Figure 1).

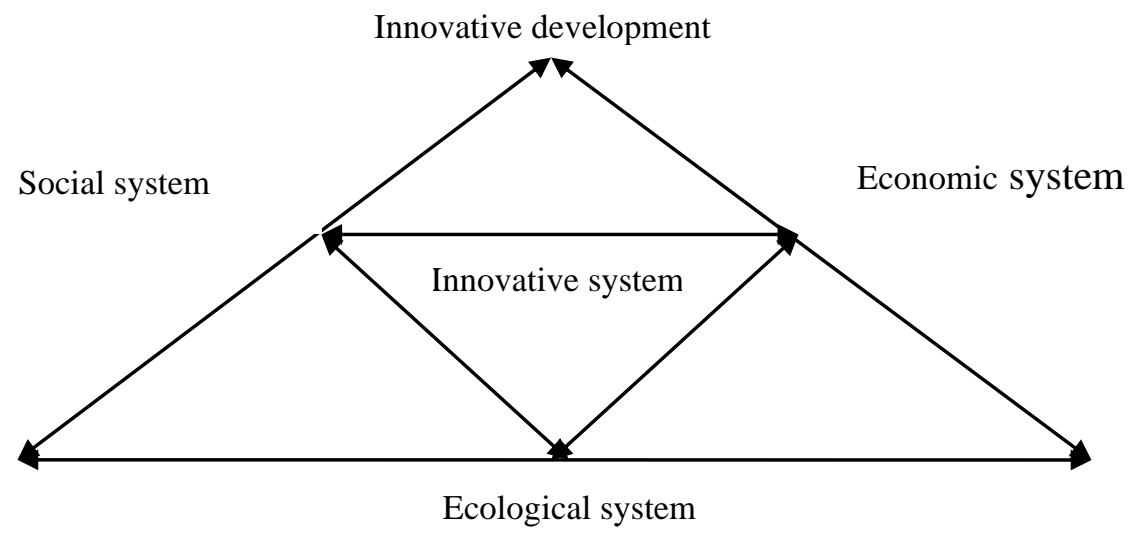

Figure 1. Schematic model of innovative development socio-ecological-economic system in the country

It should be noted that there is a lack of comprehensive research, methodological developments and methodical approaches regarding evaluation the state of development of all systems in the country. Understanding the sphere of the country's vital activity as a complex socio-ecological-economic system, the elements of which are interconnected and interdependent, justifies the method of evaluating the level of its innovative development using a complex indicator. The innovativeness of economic, ecological and social system is proposed to evaluate as an integral indicator. The proposed method for evaluation the level of the country's innovative development provides the following algorithm of actions: determination of an integral (group) indicators list; selection of an indices list for integral indicators; calculation of indices for each integral indicator; calculation of an integral indicators; calculation of a complex indicator.

According to the algorithm, the list of integral indicators of the socio-ecologicaleconomic system's innovativeness has been determined. A list of indices for integral indicators is proposed (Table 1).

Table 1. Indicators and indices

of country's socio-ecological-economic system innovativeness

\begin{tabular}{|c|c|l|c|}
\hline $\begin{array}{c}\text { Integral } \\
\text { indicator }\end{array}$ & $\begin{array}{c}\text { Indicator } \\
\text { designation }\end{array}$ & \multicolumn{1}{|c|}{ Index } & Index designation \\
\hline $\begin{array}{c}\text { Indicator } \\
\text { of economic system } \\
\text { innovativeness }\end{array}$ & $I_{E c o n S I}$ & Index of gross domestic expenditure on R\&D & $I_{G E R D}$ \\
\cline { 3 - 4 } & & Index of environmental protection investments & $I_{E P I}$ \\
\cline { 3 - 4 } & & Index of renewable sources energy & $I_{R S E}$ \\
\cline { 3 - 4 } & & Index of intellectual property receipts & $I_{H T N E}$ \\
\cline { 3 - 4 } & & Index of high-tech net exports & $I_{I C T S E}$ \\
\cline { 3 - 4 } & & Index of ICT services exports & $I_{Q L L}$ \\
\hline Indicator & $I_{S o c S I}$ & Index of healthy life expectancy & $I_{Q L}$ \\
\cline { 3 - 4 } & & Quality of life index & \\
\hline
\end{tabular}




\section{Sciendo}

Management Theory and Studies for Rural Business and Infrastructure Development

eISSN 2345-0355. 2021. Vol. 43. No. 1: 161-171

Article DOI: https://doi.org/10.15544/mts.2021.14

\begin{tabular}{|c|l|l|c|}
\hline innovativeness & & Index of net reproduction rate & $I_{N R R}$ \\
\hline \multirow{2}{*}{$\begin{array}{c}\text { Indicator } \\
\text { of ecological system } \\
\text { innovativeness }\end{array}$} & \multirow{2}{*}{$I_{E c o l S I}$} & Atmosphere quality index & $I_{A Q}$ \\
\cline { 3 - 4 } & & Climate Change Performance index & $I_{C C P}$ \\
\cline { 3 - 4 } & & Environmental Performance index & $I_{E P}$ \\
\hline
\end{tabular}

There are six indices were selected to characterize the innovativeness of the economic system: index of gross domestic expenditure on research and development (R\&D), index of environmental protection investments, index of renewable sources energy, index of intellectual property receipts, index of high-tech net exports, index of information and communication technologies (ICT) services exports. It is proposed to characterize the innovation of the social system by three indices: index of healthy life expectancy, quality of life index, index of net reproduction rate (population). There are also three indices to characterize the innovativeness of the ecological system: atmosphere quality index, climate change performance index, environmental performance index. The choice of indices was based on the possibility of obtaining them from available statistical databases.

Indices $(I g)$ are calculated as the ratio of statistics data by a particular country and EU country, which has the maximum value for a certain characteristic among member countries, according to the formula:

$$
I g=\frac{S_{c g}}{S_{c g E U}},
$$

where $\mathrm{S}_{\mathrm{cg}}$ is the statistical value of $\mathrm{g}$ index by the country; $\mathrm{S}_{\mathrm{cg} U E}$ is the maximum statistical value of g-index by EU member country.

Selected indices are factors-stimulant. An explanation is needed for atmosphere quality index, which uses statistics by pollution index, which is a factor-de-stimulant. Therefore, atmosphere quality index is calculated as $I g=\frac{S_{c g E U}}{S_{c g}}$ which is a factor-destimulant.

Integral indicators $\left(I_{S I}\right)$ are calculated as a geometric mean value by the formula:

$$
I_{S I i}=\sqrt[m]{I_{g 1} \times I_{g 2} \times \ldots \times I_{g m}}
$$

where $\mathrm{m}-$ the number of indices in the integral indicator.

The complex indicator of the socioecological-economic system innovativeness $\left(C I_{\text {ISEES }}\right)$ is calculated as the arithmetic mean value by the formula:

$$
C_{\text {ISEES }}=\frac{1}{n} \sum_{i=1}^{n} I_{S I i}
$$

where $I_{S I i}$ is the value of the $i$-th integral indicator; $n$ is the number of indicators (set to $3)$.

At the same time

$$
0 \leq I_{S I i} \leq 1,0 \leq C I_{\text {ISEES }} \leq 1 .
$$

The choice of calculating the complex indicator as the arithmetic mean value is due to the fact that according to the interviewed experts at this stage the development of social, ecological and economic systems are equally important.

In the future, a transition to the calculation of a complex indicator is possible, taking into account the importance of each of the systems for the country's innovative development.

The level of the country's socioecological-economic system innovativeness is

Copyright (C 2021 Author(s), published by Vytautas Magnus University. This is an open access article distributed under the terms of the Creative Commons Attribution Non-Commercial 4.0 (CC BY-NC 4.0) license, which permits unrestricted use, distribution, and reproduction in any medium provided the original author and source are credited. The material cannot be used for commercial purposes. 
proposed to be determined based on six gradations of the complex indicator:

$0.0 \leq C I_{\text {ISEES }}<0.2$ - unsatisfactory;

$0.2 \leq C I_{\text {ISEES }}<0.4-$ low;

$0.4 \leq C I_{\text {ISEES }}<0.6$ - satisfactory;

$0.6 \leq C I_{\text {ISEES }}<0.8$ - sufficient;

$0.8 \leq C I_{\text {ISEES }} \leq 1.0-$ high.

Gradations of the complex indicator are established by the expert method.

Statistical data of official bodies, international and European organizations, rating agencies for 2019 were used as the initial data: Eurostat, Ukrstat, Global Innovation Index, Global health organization, Numbeo organization, Undata a world of information, Climate Change Performance index, Environmental Performance.

The calculated values of the indices and integral indicator of economic system innovativeness in Ukraine and the EU member states in 2019 are given in Table 2.

According to the results of calculations, the integral indicator of the economic system innovativeness of Ukraine is 4.75 times less than the highest value in the EU member states, namely Sweden. This country has achieved such results due to large of gross domestic expenditure on $R \& D$ and a significant share of renewable energy sources. Due to these factors, Finland, which is second after Sweden, has also achieved high results of the economic system innovativeness. The Netherlands is shaping an innovative economy based on intellectual assets and environmental protection investments. The value of the integral indicator of the economic system innovativeness in Ukraine is slightly higher than in Greece, which has the lowest level among the EU member states.

Table 2. Values of indices and integral indicator of economic system innovativeness in Ukraine and the EU member states

\begin{tabular}{|l|c|c|c|c|c|c|c|}
\hline \multicolumn{1}{|c|}{ Country } & $I_{\text {GERD }}$ & $I_{\text {EPI }}$ & $I_{\text {RSE }}$ & $I_{I P R}$ & $I_{\text {HTNE }}$ & $I_{\text {ICTSE }}$ & $I_{\text {EconSI }}$ \\
\hline Ukraine & 0.106 & 0.586 & 0.087 & 0.029 & 0.117 & 0.212 & 0.125 \\
\hline Belgium & 0.853 & 0.714 & 0.176 & 0.129 & 0.474 & 0.132 & 0.309 \\
\hline Bulgaria & 0.248 & 0.571 & 0.382 & 0.014 & 0.222 & 0.132 & 0.168 \\
\hline Czechia & 0.572 & 1.000 & 0.288 & 0.043 & 1.000 & 0.101 & 0.299 \\
\hline Denmark & 0.873 & - & 0.660 & 0.243 & 0.304 & 0.119 & 0.347 \\
\hline Germany & 0.935 & 0.571 & 0.308 & 0.171 & 0.673 & 0.101 & 0.352 \\
\hline Estonia & 0.475 & 0.714 & 0.566 & 0.014 & 0.503 & 0.159 & 0.245 \\
\hline Ireland & 0.230 & 0.286 & 0.212 & 0.400 & 0.579 & 1.000 & 0.384 \\
\hline Greece & 0.375 & 0.143 & 0.349 & 0.014 & 0.117 & 0.071 & 0.114 \\
\hline Spain & 0.336 & 0.286 & 0.325 & 0.071 & 0.228 & 0.128 & 0.200 \\
\hline France & 0.646 & 0.571 & 0.305 & 0.286 & 0.749 & 0.097 & 0.364 \\
\hline Croatia & 0.327 & 0.714 & 0.505 & 0.029 & 0.181 & 0.123 & 0.206 \\
\hline Italy & 0.428 & 0.429 & 0.323 & 0.100 & 0.310 & 0.071 & 0.225 \\
\hline Cyprus & 0.186 & 0.429 & 0.245 & 0.000 & 0.023 & 0.643 & 0.196 \\
\hline Latvia & 0.189 & 0.429 & 0.727 & 0.000 & 0.433 & 0.167 & 0.336 \\
\hline Lithuania & 0.292 & 0.286 & 0.452 & 0.014 & 0.345 & 0.044 & 0.141 \\
\hline Luxembourg & 0.351 & 0.429 & 0.125 & 0.286 & 0.035 & 0.154 & 0.175 \\
\hline Hungary & 0.437 & 0.571 & 0.224 & 0.229 & 0.731 & 0.084 & 0.304 \\
\hline Malta & 0.180 & 0.143 & 0.151 & 0.357 & 0.222 & 0.022 & 0.138 \\
\hline Netherlands & 0.637 & 0.714 & 0.156 & 1.000 & 0.655 & 0.159 & 0.441 \\
\hline Austria & 0.941 & 0.286 & 0.596 & 0.086 & 0.439 & 0.132 & 0.305 \\
\hline Poland & 0.389 & 0.429 & 0.216 & 0.029 & 0.380 & 0.101 & 0.185 \\
\hline Portugal & 0.413 & 0.429 & 0.543 & 0.014 & 0.158 & 0.075 & 0.159 \\
\hline Romania & 0.142 & 0.286 & 0.431 & 0.014 & 0.246 & 0.216 & 0.153 \\
\hline Slovenia & 0.602 & 0.857 & 0.384 & 0.029 & 0.263 & 0.071 & 0.218 \\
\hline Slovakia & 0.245 & 0.571 & 0.300 & 0.000 & 0.538 & 0.075 & 0.279 \\
\hline Finland & 0.823 & 0.429 & 0.764 & 0.471 & 0.257 & 0.357 & 0.476 \\
\hline Sweden & 1.000 & 0.714 & 1.000 & 0.529 & 0.427 & 0.273 & 0.594 \\
\hline United Kingdom & 0.519 & 0.429 & 0.219 & 0.371 & 0.526 & 0.141 & 0.332 \\
\hline & & & & & & &
\end{tabular}




\section{sciendo}

Management Theory and Studies for Rural Business and Infrastructure Development

eISSN 2345-0355. 2021. Vol. 43. No. 1: 161-171

Article DOI: https://doi.org/10.15544/mts.2021.14

To increase the level of the economic system innovativeness in Ukraine, it is necessary to focus on the indices with the worst level. Primarily, it is necessary to use tools for the development of intellectual property, hightech exports. The experience of the EU member states with higher values of these indices will be useful.

The calculated values of the indices and integral indicator of social system innovativeness in Ukraine and the EU member states in 2019 are given in Table 3.

The integral indicator of social system innovativeness in Ukraine is much lower than in the EU member states, even in such as Greece, Bulgaria and Hungary, which have low its level. The highest level of this system innovativeness is noted in Denmark and Sweden. If in Denmark the success factors are quality of life and healthy life expectancy, in Sweden such are healthy life expectancy and net reproduction rate. To increase the level of the social system innovativeness in Ukraine, it is necessary to introduce a mechanism whose tools will be aimed at quality of life, precisely because of the low level of this index. The experience of all developed the EU member states will be useful.

Table 3. The value of indices and an integral indicator of the social system innovativeness in Ukraine and the EU member states

\begin{tabular}{|l|c|c|c|c|}
\hline \multicolumn{1}{|c|}{ Country } & $I_{H A L E}$ & $I_{Q L}$ & $I_{N R R}$ & $I_{\text {SocSI }}$ \\
\hline Ukraine & 0.902 & 0.515 & 0.767 & 0.709 \\
\hline Belgium & 0.975 & 0.816 & 0.922 & 0.902 \\
\hline Bulgaria & 0.906 & 0.658 & 0.833 & 0.792 \\
\hline Czechia & 0.961 & 0.800 & 0.878 & 0.877 \\
\hline Denmark & 0.978 & 1.000 & 0.944 & 0.974 \\
\hline Germany & 0.975 & 0.942 & 0.856 & 0.923 \\
\hline Estonia & 0.954 & 0.911 & 0.844 & 0.902 \\
\hline Ireland & 0.983 & 0.810 & 0.989 & 0.923 \\
\hline Greece & 0.978 & 0.694 & 0.700 & 0.780 \\
\hline Spain & 1.000 & 0.877 & 0.711 & 0.854 \\
\hline France & 0.999 & 0.795 & 1.000 & 0.926 \\
\hline Croatia & 0.955 & 0.833 & 0.778 & 0.852 \\
\hline Italy & 0.996 & 0.734 & 0.711 & 0.804 \\
\hline Cyprus & 0.979 & - & 0.711 & 0.834 \\
\hline Latvia & 0.929 & - & 0.911 & 0.920 \\
\hline Lithuania & 0.933 & 0.787 & 0.889 & 0.867 \\
\hline Luxembourg & 0.992 & - & 0.778 & 0.879 \\
\hline Hungary & 0.936 & 0.677 & 0.800 & 0.797 \\
\hline Malta & 0.992 & - & 0.778 & 0.879 \\
\hline Netherlands & 0.987 & 0.951 & 0.889 & 0.941 \\
\hline Austria & 0.987 & 0.962 & 0.822 & 0.921 \\
\hline Poland & 0.954 & 0.745 & 0.767 & 0.817 \\
\hline Portugal & 0.982 & 0.823 & 0.689 & 0.823 \\
\hline Romania & 0.930 & 0.707 & 0.867 & 0.829 \\
\hline Slovenia & 0.983 & 0.886 & 0.856 & 0.907 \\
\hline Slovakia & 0.947 & 0.771 & 0.811 & 0.840 \\
\hline Finland & 0.983 & 0.977 & 0.822 & 0.924 \\
\hline Sweden & 0.997 & 0.900 & 0.989 & 0.961 \\
\hline United Kingdom & 0.966 & 0.860 & 0.944 & 0.922 \\
\hline & & & & \\
\hline
\end{tabular}

Copyright (C) 2021 Author(s), published by Vytautas Magnus University. This is an open access article distributed under the terms of the Creative Commons Attribution Non-Commercial 4.0 (CC BY-NC 4.0) license, which permits unrestricted use, distribution, and reproduction in any medium provided the original author and source are credited. The material cannot be used for commercial purposes. 
Management Theory and Studies for Rural Business and Infrastructure Development

eISSN 2345-0355. 2021. Vol. 43. No. 1: 161-171

Article DOI: https://doi.org/10.15544/mts.2021.14

The calculated values of the indices and integral indicator of ecological system innovativeness in Ukraine and the EU member states in 2019 are given in Table 4.

According to the results of calculations, the integral indicator of the ecological system innovativeness in Ukraine is more than two times less than the highest value in the EU member states, which belongs to Finland. In this country, the high level of the indicator is due to the highest value of the atmosphere quality index, as well as the rather high level of environmental performance index. The lowest level of the indicator is noted in Bulgaria, in Ukraine it slightly higher. The indicators that were calculated for Poland have similar values.

To increase the integral indicator of the ecological system innovativeness in Ukraine, it is necessary to use the experience of the EU member states in the formation of tools for influencing atmosphere quality.

Table 4. The value of indices and an integral indicator of the ecological system innovativeness in Ukraine and the EU member states

\begin{tabular}{|l|c|c|c|c|}
\hline \multicolumn{1}{|c|}{ Country } & $I_{A Q}$ & $I_{C C P}$ & $I_{E P}$ & $I_{\text {EcolSI }}$ \\
\hline Ukraine & 0.179 & 0.745 & 0.600 & 0.431 \\
\hline Belgium & 0.239 & 0.606 & 0.888 & 0.505 \\
\hline Bulgaria & 0.186 & 0.573 & 0.691 & 0.419 \\
\hline Czechia & 0.291 & 0.524 & 0.861 & 0.508 \\
\hline Denmark & 0.539 & 0.933 & 1.000 & 0.795 \\
\hline Germany & 0.426 & 0.758 & 0.936 & 0.671 \\
\hline Estonia & - & 0.618 & 0.792 & 0.700 \\
\hline Ireland & 0.383 & 0.611 & 0.882 & 0.591 \\
\hline Greece & 0.231 & 0.646 & 0.838 & 0.500 \\
\hline Spain & 0.303 & 0.605 & 0.901 & 0.549 \\
\hline France & 0.279 & 0.722 & 0.970 & 0.580 \\
\hline Croatia & 0.384 & 0.762 & 0.765 & 0.607 \\
\hline Italy & 0.222 & 0.713 & 0.861 & 0.515 \\
\hline Cyprus & - & 0.520 & 0.785 & 0.639 \\
\hline Latvia & - & 0.831 & 0.747 & 0.788 \\
\hline Lithuania & 0.387 & 0.780 & 0.762 & 0.613 \\
\hline Luxembourg & - & 0.742 & 0.998 & 0.861 \\
\hline Hungary & 0.257 & 0.514 & 0.772 & 0.467 \\
\hline Malta & - & 0.836 & 0.857 & 0.846 \\
\hline Netherlands & 0.435 & 0.685 & 0.913 & 0.648 \\
\hline Austria & 0.543 & 0.646 & 0.965 & 0.697 \\
\hline Poland & 0.228 & 0.523 & 0.738 & 0.445 \\
\hline Portugal & 0.378 & 0.763 & 0.812 & 0.616 \\
\hline Romania & 0.215 & 0.676 & 0.784 & 0.485 \\
\hline Slovenia & 0.490 & 0.497 & 0.873 & 0.597 \\
\hline Slovakia & 0.285 & 0.665 & 0.828 & 0.539 \\
\hline Finland & 1.000 & 0.842 & 0.956 & 0.930 \\
\hline Sweden & 0.662 & 1.000 & 0.954 & 0.858 \\
\hline United Kingdom & 0.303 & 0.936 & 0.985 & 0.654 \\
\hline & & & & \\
\hline
\end{tabular}

The complex indicator value of the socioecological-economic system innovativeness in
Ukraine is lower than in the EU member states (Figure 2). According to the accepted

Copyright (C) 2021 Author(s), published by Vytautas Magnus University. This is an open access article distributed under the terms of the Creative Commons Attribution Non-Commercial 4.0 (CC BY-NC 4.0) license, which permits unrestricted use, distribution, and reproduction in any medium provided the original author and source are credited. The material cannot be used for commercial purposes. 
gradations, the complex indicator has a satisfactory level (close to the lower threshold). The most problematic is the integral indicator of the economic system innovativeness, which has the least value that was inserted for the analyzed systems.
The countries that are close to Ukraine in terms of the complex indicator of innovative development are Bulgaria and Slovakia. Twelve the EU member states, such as Denmark, Germany, Estonia, Ireland, France, Latvia, Luxembourg, Malta, the Netherlands, Austria, Finland and the United Kingdom, have a sufficient level of innovative development.

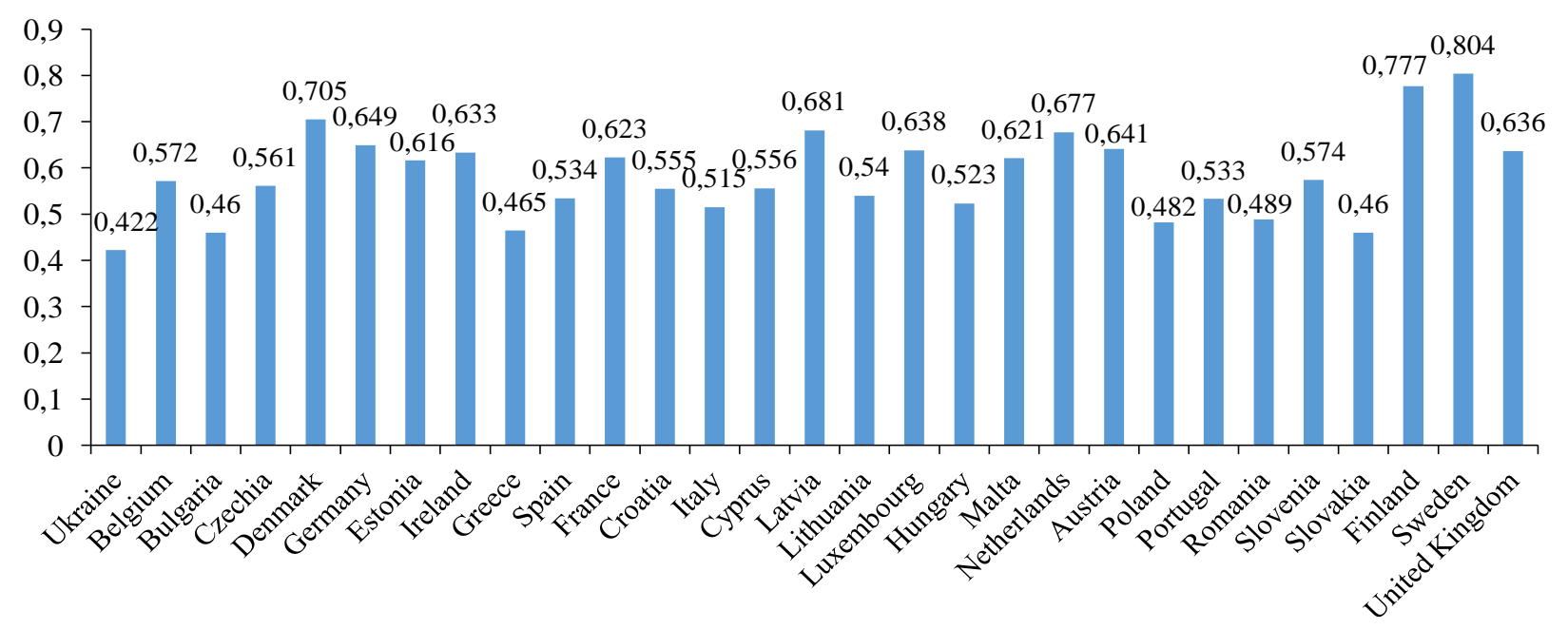

Figure 2. Values of complex indicator of the socio-ecological-economic system innovativeness in the countries

The highest value of the complex indicator among the EU member states was noted in Sweden. Its value is almost twice as high as in Ukraine. Sweden is a country with a high level of the socio-ecological-economic system innovativeness.

\section{Conclusions}

The article substantiates that development is based on innovation. The problem of innovative development is recognized as a priority in most countries of the world. In Ukraine, the national innovation system has just begun to form, so scientists are making efforts to solve it. Researches and practitioners have recognized that the modern trajectory of the country's innovative development is ensured by the results of activities within the framework of the national innovation system. However, in most studies, a significant number of indicators used to evaluate indicate the potential of the national innovation system, but not its results. This study proves that the results of the innovative development should be considered in all spheres of the country's vital activity, the main components of which are the social, ecological and economic systems. Therefore, the proposed model is focused on the innovativeness of the socio-ecological-economic system.

It is offered to evaluate the innovativeness of the systems as an integral indicator, which is calculated as the geometric

Copyright (C 2021 Author(s), published by Vytautas Magnus University. This is an open access article distributed under the terms of the Creative Commons Attribution Non-Commercial 4.0 (CC BY-NC 4.0) license, which permits unrestricted use, distribution, and reproduction in any medium provided the original author and source are credited. The material cannot be used for commercial purposes. 
mean value of certain indices. A list of indices for economic, social and ecological systems is proposed. Twelve indices were selected that characterize innovativeness and are included in three integrated indicators. Each of the integrated indicators has an individual of indices that reflect the innovativeness of the certain component socio-ecological-economic system. It is proposed to characterize the innovativeness of the economic system by six indices. Three indices were selected to characterize the innovativeness of social system. Also, three indices will characterize the innovativeness of the ecological system. The best data of a particular the EU country were used as reference values when calculating indices. It was recommended to calculate a complex indicator of innovativeness for a country as an arithmetic mean value of three integrated indices. A gradation of a complex indicator of the socio-ecological-economic system innovativeness with five levels (high, sufficient, satisfactory, low, unsatisfactory) is proposed. The value of the complex indicator shows that the innovativeness of the socioecological-economic system in Ukraine has a satisfactory level, but is close to the lower threshold. The level of innovative development in Ukraine is close to that of Bulgaria and Slovakia, but is lower than in others the EU member states. For Ukraine, the most problematic is the innovativeness of the economic system, the integral indicator for which has the least value among the components of the system. To increase the level of the economic system innovativeness in Ukraine, it is necessary to focus attention on the indices with the worst level, and these are intellectual property and high-tech exports.

Among the EU member states there are leaders in the sphere of the socio-ecologicaleconomic system innovativeness. Finland's innovative development is based on a high level of environmental performance, like Sweden. Denmark and Sweden are successful in the social system. Finland and Sweden have a high level of the innovativeness economic component of system. This accounts for the high value of the complex indicator by Sweden among the EU member states. According to the accepted gradation of the complex indicator, Sweden is a country that has a high level of the socio-ecological-economic system innovativeness. The value of the complex indicator for Sweden is almost twice that for Ukraine. The application of the experience of these countries, as well as Germany, Estonia, Ireland, France, Latvia, Luxembourg, Malta, the Netherlands, Austria, Finland, the United Kingdom, in terms of innovative development tools will allow Ukraine to form an effective innovation model and realize the aspiration to integrate into the EU.

\section{References}

Alvarez-Herranz, A., Balsalobre-Lorente, D., Shahbaz, M., Cantos J.M. (2017). Energy innovation and renewable energy consumption in the correction of air pollution levels // Energy Policy. Vol.105: 386-397. https://doi.org/10.1016/j.enpol.2017.03.009.

Anopchenko, T.Y., Paytaeva, K.T., Novoseltseva, L.A., Chernyshev, M.A., Murzin, A.D. (2015). Socioecological modeling of risk factors of urbanized territories' development // Biosciences Biotechnology Research Asia. Vol.12(3): 2563-2579. - https://doi.org/10.13005/bbra/1936.

Bristow, G., Healy, A. (2018). Innovation and regional economic resilience: an exploratory analysis // The Annals of Regional Science. Vol.60(2): 265-284. - https://doi.org/10.1007/s00168-017-0841-6.

Burduli, V., Abesadze, R. (2017). Experience of transformation of national innovation systems in developed countries and directions of its use in Georgia // International journal of new economics and social sciences. Vol.5(1): 301-311. - https://doi.org/10.5604/01.3001.0010.4265.

Coccia, M. (2014). Socio-cultural origins of the patterns of technological innovation: what are the likely interaction among religious culture, religious plurality, and innovation? Towards a theory of socio-cultural drivers of the patterns of technological innovation // Technology in Society. Vol.36(1): 13-25. https://doi.org/10.1016/j.techsoc.2013.11.002.

Diatlova, V., Petryk, I. (2019). Strategic approach to renewable energy development: EU experience // Central Ukrainian Scientific Bulletin. Economic sciences. Vol.2(35): 9-19. - https://doi.org/10.32515/2663-1636.2019.2(35).919. 
Management Theory and Studies for Rural Business and Infrastructure Development

eISSN 2345-0355. 2021. Vol. 43. No. 1: 161-171

Article DOI: https://doi.org/10.15544/mts.2021.14

Dudin, M., Lyasnikov, N., Veselovsky, M., Sekerin, V., Aleksakhina, V. (2014). The Problem of Forecasting and Modelling of the Innovative Development of Social-Economic Systems and Structures // Life Science Journal. Vol.11(8): 549-552. - https://doi.org/10.13140/RG.2.1.1111.1840.

Dutta, S., Lanvin, B., Wunsch-Vincent, S. (Eds.). (2019). Global innovation index 2019, Creating healthy lives the future of medical innovation. $12^{\text {th }}$ ed. $451 \quad$ p. $\quad-\quad$ https:// www.globalinnovationindex.org/userfiles/file/reportpdf/gii-full-report-2019.pdf [09 12 2020].

Gurman, V.I., Matveev, G.A., Trushkova, E.A. (2013). The socio-ecological-economic model of a region in parallel computing // Automation and Remote Control. Vol.74(4): 697-709. https://doi.org/10.1134/S0005117913040139.

Holmén, M., Magnusson, M., McKelvey, M. (2007). What are innovative opportunities? // Industry and innovation. Vol.14(1): 27-45. - https://doi.org/10.1080/13662710601130830.

Janssen, M. (1998). Modeling global change: the art of integrated assessment modeling. 1st. ed. Edward Elgar Pub. Lyme, Connecticut. 262 p.

Li, C., Shen, B. (2019). Accelerating renewable energy electrification and rural economic development with an innovative business model: A case study in China // Energy Policy. Vol.127: 280-286. https://doi.org/10.1016/j.enpol.2018.12.009.

Matvieieva, Y., Myroshnychenko, I., Valenkevych, L. (2019). Optimization Model of the Socio-Ecological-Economic Development of the Administrative Territory // Journal of Environmental Management and Tourism. Vol.10(8): 1874-1885. https://doi.org/10.14505//jemt.10.8(40).17.

Nesta, L., Vona, F., Nicolli, F. (2014). Environmental policies, competition and innovation in renewable energy // Journal of Environmental Economics and Management. Vol.67(3): $396-411 . \quad-$ https://doi.org/10.1016/j.jeem.2014.01.001.

Ramazanov, S., Antoshkina, L., Babenko, V., Akhmedov, R. (2019). Integrated model of stochastic dynamics for control of a socio-ecological-oriented innovation economy // Periodicals of Engineering and Natural Sciences. Vol.7(2): 763-773. - https://doi.org/10.21533/pen.v7i2.557.

Rosser, J.B. (2001). Complex Ecologic-Economic Dynamics and Environmental Policy? // Ecological Economics. Vol.37: 23-37. - https://doi.org/10.2139/ssrn.294681.

Szopik-Depczyńska, K., Cheba, K., Bąk, I., Kędzierska-Szczepaniak, A., Szczepaniak, K., Ioppolo, G. (2020). Innovation level and local development of EU regions. A new assessment approach // Land Use Policy. Vol.99: 1048373. - https://doi.org/10.1016/j.landusepol.2020.104837.

Tanashchuk, E.A., Kovtunenko, K.V., Kovtunenko, Yu.V. (2018). Theoretical and Methodical Principles of Capital Structure Management in the Innovation Activity of Telecommunication Operators // Journal of Automation and Information Sciences. Vol.50(3): 71-84. - https://doi.org/10.1615/JAutomatInfScien.v50.i3.60.

Wang, Q., Miao, X. (2020). Innovative Ecological Economic System Based on 5G Network and Internet of Things // Microprocessors and Microsystems. Vol.8: 103558. - https://doi.org/10.1016/j.micpro.2020.103558.

Zhukov, R.A. (2018). Model of Socio-Ecological and Economic System: the Central Federal District Regions of the Russian Federation // Statistika. $237-261$. https://www.czso.cz/documents/10180/61266313/32019718q3237.pdf/00aebdf2-79d5-4ec1-8559-

e1bc7c14b29c?version=1.0 [09 12 2020].

Zos-Kior, M., Hnatenko, I., Isai, O., Shtuler, I., Samborskyi, O., Rubezhanska, V. (2021). Management of efficiency of the energy and resource saving innovative projects at the processing enterprises // Management Theory and Studies for Rural Business and Infrastructure Development. Vol.42. No.4: 504-515. https://doi.org/10.15544/mts.2020.52

Zvieriakov, M.I., Zavadska, D.V. (2018). Model of intensive innovative development: world experience of implementation and trends of formation in Ukraine // Scientific Bulletin of National Mining University. Vol.5: $155-166$. - https://doi.org/10.29202/nvngu/2018-5/19.

Copyright (C 2021 Author(s), published by Vytautas Magnus University. This is an open access article distributed under the terms of the Creative Commons Attribution Non-Commercial 4.0 (CC BY-NC 4.0) license, which permits unrestricted use, distribution, and reproduction in any medium provided the original author and source are credited. The material cannot be used for commercial purposes. 